\title{
IMPLIKASI PENGEMBANGAN PEMBANGUNAN INFRASTRUKTUR KAWASAN JALAN BARU MUARO - AIR MANIS TERHADAP TATA RUANG DI KELURAHAN BUKIT GADO-GADO KOTA PADANG
}

\author{
Erwin Idris Pratama Nasution \\ Jurusan Administrasi Publik, Fakultas Ilmu Sosial, Universitas Negeri Padang \\ Email: erwinn.nasution@gmail.com \\ Afriva Khaidir \\ Jurusan Administrasi Publik, Fakultas Ilmu Sosial, Universitas Negeri Padang \\ Email: afrivak@yahoo.com
}

\begin{abstract}
This study aimed to find out the implications of the development of the new Muaro - Air Manis Road Infrastructure Development for Spatial Planning in Bukit Gado-Gado Village, Padang City. This study used qualitative approach that produced descriptive data with the intention of conducting research, describing, and analyzing the implications of the development of the Jalan Baru Muaro Infrastructure Development Area - Air Manis Against Spatial Planning in Bukit Gado-Gado Village, Padang City. Data was collected through interview, observation and documentation study. In this study the analyzed data were obtained from interviews and interpreted qualitatively in the form of abstractions, words and statements. The results of the study showthe implications of infrastructure development in the area of Baru Muaro Street - Air Manis for spatial planning in the district of Gado-Gado Hill, Padang City. The implementation of infrastructure development has been carried out in accordance with the spatial strategy carried out covering 3 things, namely : (1) consistent cultural control, (2) strengthen economic base, (3) forming an efficient development unit, but in the implementation there are stil some obstacles faced by both internal and external constraints. The efforts made by the government to marginalize the existing constraints is include in increasing people's understanding of Local Regulation (Perda) No. 4 of 2012 concerning RTRW through socialization and intercession, also increasing infrastructure development in the layout area of Gado-Gado Hill.
\end{abstract}

Keywords: Infrastructure, spatial planning, development 


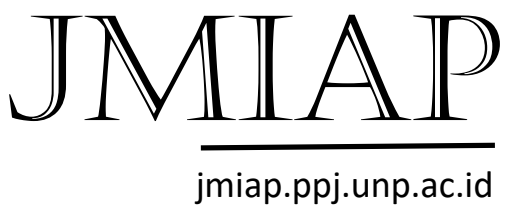

\section{Pendahuluan}

Sejalan dengan perkembangan dan pertumbuhan Pembangunan Nasional pada era globalisasi sekarang ini, perkembangan pembangunan di Kota Padang menampakkan adanya kemajuan yang sangat pesat, baik di bidang teknologi ataupun di bidang pembangunan. Dalam situasi otonomi daerah yang diberlakukan pada saat ini, pemerintah maupun masyarakat mempunyai peranan sangat penting kepada tatanan dan wajah Kota mendatang, sehingga perlu adanya kegiatan otonomi daerah dalam arti pemerintah daerah mengatur wilayahnya sendiri tanpa diikutsertakan kewenangan pemerintah pusat.

Menurut Peraturan Daerah No.4 tahun 2012 tentang Rencana Tata Ruang Wilayah Kota Padang, tujuan penataan ruang adalah menciptakan hubungan yang serasi antara berbagai kegiatan diberbagai subwilayah agar tercipta hubungan yang harmonis dan serasi. Penataan ruang akan selalu berkaitan dengan pengembangan pembangunan infrastruktur.

Pembangunan adalah proses perubahan masyarakat dalam dimensi kuantitatif dan kualitatif, dimana adanya perubahan pemikiran masyarakat yang awalnya berorientasi secara tradisional menjadi modern. Sedangkan yang di maksud dengan infrastruktur adalah Menurut Kodoatie (2005) infrastruktur adalah sistem yang menopang sistem sosial \& sistem ekonomi yang sekaligus menjadi penghubung dengan sistem lingkungan, dimana sistem ini dapat dipakai sebagai dasar di dalam mengambil kebijakan.

Kawasan yang dijadikan sebagai objek penelitian yaitu Bukit Gado-Gado Kota Padang. Bukit ini berlokasi di Jalan Baru Muaro Kecamatan Padang Selatan. Dimana masih rendahnya kesadaran
JURNAL ILMU ADMINISTRASI PUBLIK

Email : jianfis.unp@gmail.com Vol.1 No.1 Tahun 2018

masyarakat akan peraturan daerah khususnya mengenai RTRW dan ditemukan permasalahan seperti banyaknya bangunan liar yang didirikan tanpa izin mendirikan bangunan. Berdasarkan penjelasan tersebut dapat dipahami bahwa Bukit Gado-Gado dapat dimanfaatkan untuk pembangunan seperti Villa maupun Rumah Kebun namun dengan material yang ringan seperti kayu. Ketentuan maksimal pembangunan sebesar 20 persen bertujuan untuk menjaga kepadatan rendah sehingga jarak antar bangunan tidak terlalu dekat. Hal tersebut yang membuat penulis tertarik untuk mengetahui implikasi dari pengembangan pembangunan infrastruktur kawasan Jalan Baru Muaro-Air Manis terhadap tata ruang di Kelurahan Bukit Gado-Gado Kota Padang.

Berdasarkan latar belakang masalah di atas, maka penulis telah melaksanakan penelitian di Bukit Gado-Gado mengenai implikasi pengembangan pembangunan terhadap tata ruang. Rumusan masalah yang dikemukakan dalam penelitian ini adalah:

1. Bagaimana pelaksanaan pengembangan pembangunan infrastruktur di kawasan Jalan Baru Muaro - Air Manis, Kelurahan Bukit Gado-Gado Kota Padang ?

2. Apa saja faktor-faktor yang mempengaruhi pelaksanaan pengembangan pembangunan infrastruktur kawasan Jalan Baru Muaro - Air Manis terhadap tata ruang di Kelurahan Bukit Gado-Gado Kota Padang ?

3. Apa saja implikasi pengembangan pembangunan infrastruktur kawasan Jalan Baru Muaro - Air Manis 


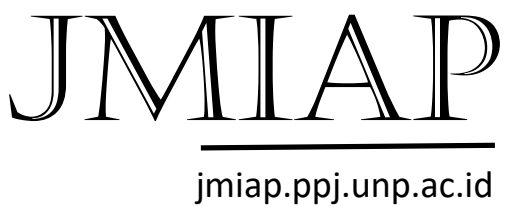

terhadap tata ruang di Kelurahan Bukit Gado-Gado Kota Padang ?

\section{Tinjauan Kepustakaan}

Konsep Pengembangan Kawasan \& Infrastruktur

Menurut Kamus Besar Bahasa Indonesia, Pengembangan berarti ekspansi, peningkatan, pembangunan, perluasan (KBBI, 2017). Pengembangan adalah suatu proses atau cara menjadikan sesuatu menjadi maju, baik, sempurna, dan berguna (Suwantoro, 1997). Jadi pengembangan adalah suatu proses untuk meningkatkan sesuatu, dengan kata lain proses menjadikan sesuatu menjadi lebih maju dan lebih baik lagi.

Menurut Direktorat Pengembangan Kawasan Strategis, Ditjen Penataan Ruang, Departemen Permukiman dan Prasarana Wilayah (2002), prinsipprinsip dasar dalam pengembangan wilayah adalah :

1. Sebagai growth center dimana pengembangan wilayah tidak hanya bersifat internal wilayah, namun harus diperhatikan sebaran atau pengaruh pertumbuhan yang dapat ditimbulkan bagi wilayah sekitarnya, bahkan secara nasional.

2. Pengembangan wilayah memerlukan upaya kerjasama pengembangan antar daerah dan menjadi persyaratan utama bagi keberhasilan pengembangan wilayah.

3. Pola pengembangan wilayah bersifat integral yang merupakan integrasi dari daerah-daerah yang tercakup dalam wilayah melalui pendekatan kesetaraan.

Pada dasarnya pembangunan merupakan pendayagunaan potensi masyarakat
JURNAL ILMU ADMINISTRASI PUBLIK

Email : jianfis.unp@gmail.com Vol.1 No.1 Tahun 2018

semaksimal mungkin dengan jalan partisipasi aktif menurut tingkat kemampuan dan keterampilan yang dimiliki. Menurut Mahi (2016) Konsep kawasan adalah wilayah yang berbasis pada keberagaman fisik dan ekonomi, tetapi memiliki hubungan erat dan saling mendukung satu sama lain secara fungsional demi mempercepat pertumbuhan ekonomi daerah dan meningkatkan kesejahteraan rakyat.

Pengembangan kawasan adalah usaha untuk mengembangkan dan meningkatkan hubungan kesalingketergantungan dan interaksi antar sistem ekonomi (economic system), masyarakat (social system), dan lingkungan hidup beserta sumber daya alamnya (ecosystem). Interaksi kepada pihak-pihak yang terkait dengan pengembangan kawasan maka hal ini mutlak diperlukan, sehingga muncul pemahaman bersama tentang pentingnya proses ini untuk mewujudkan pembangunan yang serasi, seimbang, dan terintegrasi.

Perencanaan pengembangan kawasan adalah suatu perencanaan berbasis prakara masyarakat, yaitu perencanaan yang sepenuhnya mencerminkan kebutuhan konkret masyarakat dalam proses penyusunannya, dan benar-benar melibatkan rakyat sekitar kawasan yang akan dikembangkan itu. Langkahlangkah perencanaan kawasan seperti dikemukakan berikut ini :

1. Perizinan dan Legalitas

2. Survei kawasan

3. Analisis kawasan

4. Penentuan lokasi kawasan

Dalam pengembangan pembangunan kawasan maka dibangun infrastruktur untuk kepentingan masyarakat umum. 
Dimana yang dimaksud infrastruktur adalah dalam Kamus Besar Bahasa Indonesia, dapat diartikan sebagai sarana dan prasarana umum. Sarana secara umum diketahui sebagai fasilitas publik seperti rumah sakit, jalan, jembatan, sanitasi, telepon, dan sebagainya. Dalam ilmu ekonomi infrastruktur merupakan wujud dari publik capital (modal publik) yang dibentuk dari investasi yang dilakukan pemerintah. Infrastruktur dalam penelitian ini meliputi jalan, jembatan, dan sistem saluran pembangunan (Mankiw, 2003).

Menurut Kodoatie (2010) infrastruktur adalah sistem yang menopang sistem sosial \& sistem ekonomi yang sekaligus menjadi penghubung dengan sistem lingkungan, dimana sistem ini dapat sistem ini dapat dipakai sebagai dasar di dalam mengambil kebijakan. Ada tiga jenis infrastruktur yaitu infrastruktur keras, infrastruktur keras non-fisik, dan infrastruktur lunak. Infrastruktur keras yaitu insfrastruktur yang memiliki bentuk fisik dan paling banyak hubungan dengan kepentingan masyarakat. Contohnya bandara, jalan raya, dermaga, dan lain-lain. Infrastruktur keras non-fisik sesuai namanya tidak memiliki bentuk fisik yang nyata akan tetapi turut mendukung infrastruktur keras lainnya. Contohnya jaringan komunikasi seperti telepon dan internet, ketersediaan air bersih, pasokan listrik, dan lain-lain.

\section{Tata Ruang}

Dalam undang-undang nomor 26 tahun 2007 tentang penataan ruang, dikemukakan bahwa struktur ruang adalah susunan pusat-pusat pemukiman dan sistem jaringan prasarana dan sarana yang berfungsi sebagai pendukung

JURNAL ILMU ADMINISTRASI PUBLIK

Email : jianfis.unp@gmail.com

Vol.1 No.1 Tahun 2018

kegiatan sosial ekonomi masyarakat yang secara hierarki memiliki hubungan fungsional. Menurut Kodoatie dan Syarief (2010) Klasifikasi penataan ruang dibagi berdasarkan sistem, fungsi utama kawasan, wilayah administratif, kegiatan kawasan dan nilai strategis kawasan, sebagai berikut :

1. Sistem

2. Fungsi utama kawasan

3. Wilayah administrative

4. Kegiatan kawasan

5. Nilai strategis kawasan.

Menurut Mahi (2016) strategi pengembangan tata ruang terkait dengan tujuan dan konsep pengembangan tata ruang yang ditetapkan, sehingga setiap bagian wilayah semakin kuat dan berdaya atas dasar potensi yang dimiliki. Strategi pengembangan tata ruang dilakukan melalui :

1. Pengendalian kegiatan budidaya secara konsisten yang dapat memutus atau mengganggu fungsi ekologis suatu ekosistem.

2. Memperkuat basis perekonomian menurut sektor-sektor unggulan pada masing-masing wilayah.

3. Membentuk satuan ruang pengembangan yang lebih efesien dari segi aksesibilitas, kondisi fisik wilayah, ketersediaan sumber daya alam, sumber daya manusia, serta prasarana pendukungnya.

4. Memperpendek hierarki fungsional dan tata kaitan (forward linkage) antara sektor primer, sekunder dan tersier melalui pengembangan.

5. Memperkuat industrial-belts yang telah terbentuk dengan mengupayakan 


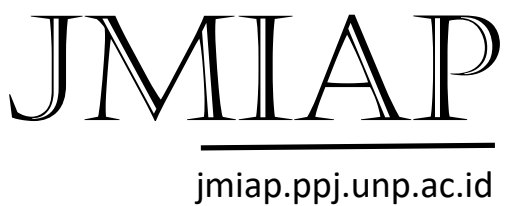

pengurangan ketergantungan terhadap pusat.

\section{Ruang terbuka hijau}

Ruang terbuka hijau adalah area memanjang/jalur dan/atau mengelompok, yang penggunaannya lebih bersifat terbuka, tempat tumbuh tanaman, baik yang tumbuh secara alamiah maupun yang sengaja ditanam. Ruang terbuka hijau public merupakan ruang terbuka yang dimiliki dan dikelola oleh pemerintah daerah kota yang digunakan unutk kepentingan masyarakat secara umum. (UU No.26, 2007 Tentang Penataan Ruang).

Tankel (dalam Haryani, 2012) membagi fungsi ruang terbuka menjadi 2 yaitu ruang terbuka yang disadari fungsinya dan ruang terbuka yang tidak disadari fungsinya. Ruang terbuka yang disadari fungsinya, memiliki 3 fungsi :

1. Penggunaannya, yaitu untuk aktifitas rekreasi aktif dan pasif yang beragam dan untuk sirkulasi

2. Pemandangannya, yaitu view ruang terbuka dari rumah dari jalan atau tempat-tempat yang cocok lainnya

3. Perasaannya, yang memberikan privasi, isolasi, keluasan dan kepala ruang.

Ruang terbuka yang tidak disadari fungsinya, memiliki dua sejenis:

1. Ruang terbuka yang melakukan tugas perkotaan, seperti menjaga persediaan air dan mencegah banjir, sebagai zona pengaman untuk penerbangan dan

2. Ruang terbuka yang membantu membentuk pola pengembangan, seperti ruang antar bangunan dan
JURNAL ILMU ADMINISTRASI PUBLIK

Email : jianfis.unp@gmail.com

Vol.1 No.1 Tahun 2018

antar komunitas, sebagai ruang saluran komunikasi dan sebagai lahan cadangan masa depan.

Ruang terbuka hijau dalam beragam bentuk, merupakan ruang terbuka yang paling nyata keberadaannya dalam struktur Kota. Ada beberapa klasifikasi taman berdasarkan bentuk. Diantaranya:

1. Taman kecil, yaitu taman kecil yang terletak pada satu hingga beberapa unit rumah biasa disebut vest-pocket parks dan umunya digunakan oleh anak-anak sebagai tempat bermain.

2. Taman kota, yaitu kawasan hijau yang cukup luas, sebagai suatu kawasan yang digunakan untuk menghabiskan waktu senggang.

3. Taman kota yang luas, yaitu Taman Kota yang luas, yaitu melayani tujuan yang lebih besar dari taman kota dan digunakan apabila taman lingkungan dan taman skala kecamatan tidak mencukupi.

4. Penggunaan khusus, yaitu yaitu taman yang berorientasi pada penggunaan tertentu saja, seperti penelitian, pendidikan, dan sebagainya.

5. Taman lingkungan, yaitu yaitu ruang terbuka yang dibangun dalam lingkungan perumahan, terbangun secara umum dan diatur sebagai kawasan ruang terbuka kota atau sebagai bagian dari pembangunan perumahan swasta.

\section{Regulasi tata ruang}

Erwin Idris Pratama Nasution, Afriva Khaidir $\mid 75$ 


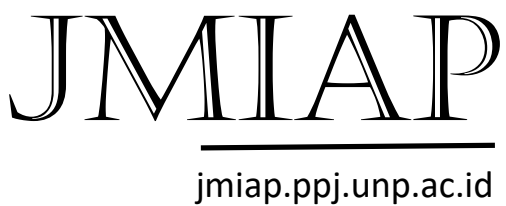

Kebijakan penataan ruang kota adalah rangkaian konsep dan asas yang menjadi garis besar dan dasar dalam pemanfaatan ruang darat, laut, dan udara termasuk ruang di dalam bumi untuk mencapai tujuan penataan ruang. Dalam kebijakan penataan ruang wilayah kota diatur dalam Perda Kota Padang No. 4 Tahun 2012. Berdasarkan Peraturan daerah Kota Padang No. 4 Tahun 2012 tersebut dalam Pasal 1 ayat 11 dijelaskan bahwa rencana tata ruang adalah hasil perencanaan tata ruang. Dengan kata lain rencana tata ruang yang bersifat umum dari wilayah Kota merupakan penjabaran dari RTRW provinsi, dan yang berisi tujuan, kebijakan, strategi penataan ruang wilayah kota, rencana struktur ruang wilayah kota, rencana pola ruang wilayah kota, penetapan kawasan strategis kota, arahan pemanfaatan ruang wilayah kota, dan ketentuan pengendalian pemanfaatan ruang wilayah kota.

Dalam Peraturan daerah Kota Padang No. 4 Tahun 2012 Pasal 5 disebutkan bahwa Penataan ruang wilayah Kota Padang dilaksanakan dengan tujuan mewujudkan Kota Padang sebagai kota metropolitan berbasis mitigasi bencana dengan didukung oleh pengembangan sektor perdagangan, jasa, industri dan parawisata. Berbagai arahan pengembangan Kota Padang tersebut dalam rangka pemerataan pembangunan seantero Kota Padang diharapkan daerah pinggiran Kota Padang dapat disentuh oleh pembangunan sehingga pada akhirnya memicu pemerataan ekonomi masyarakat Kota Padang. (Haryani,2012).

Tujuan rancana tata ruang wilayah Kota Padang adalah tujuan yang ditetapkan pemerintah daerah kota yang merupakan
JURNAL ILMU ADMINISTRASI PUBLIK

Email : jianfis.unp@gmail.com

Vol.1 No.1 Tahun 2018

arahan perwujudan visi dan misi pembangunan jangka panjang kota pada aspek keruangan, yang pada dasarnya mendukung terwujudnya ruang wilayah nasional yang aman, nyaman, produktif, dan berkelanjutan berlandaskan Wawasan Nusantara dan Ketahanan Nasional. Dalam pasal 5 disebutkan bahwa Penataan ruang wilayah Kota Padang dilaksanakan dengan tujuan mewujudkan Kota Padang sebagai kota metropolitan berbasis mitigasi bencana dengan didukung oleh pengembangan sektor perdagangan, jasa, industri dan parawisata.

\section{Metode Penelitian}

Jenis penelitian ini adalah penelitian kualitatif dengan menggunakan metode Deskriptif. Penelitian ini dilakukan di Dinas PUPR Kota Padang, Kantor Camat Padang Selatan, dan Kantor Lurah Bukit Gado-Gado. Informan ditentukan dengan cara purposive sampling, yaitu menentukan informan dengan pertimbangan tertentu yang di pandang dapat memberikan data secara maksimal.

Jenis dan sumber data pada penelitian ini ialah data primer dan data sekunder. Data primer pada penelitian ini diperoleh melalui wawancara dan observasi yang berkaitan dengan pengembangan pembangunan infrastruktur kawasan Jalan Baru Muaro - Air Manis terhadap tata ruang di Kelurahan Bukit Gado-Gado Kota Padang, sedangkan data sekunder diperoleh melalui dokumen seperti peraturan perundang-undangan yang berkaitan dengan penelitian ini. Sedangkan keabsahan data dilakukan dengan menggunakan teknik triangulasi sumber dan kecukupan referensi. Teknik 


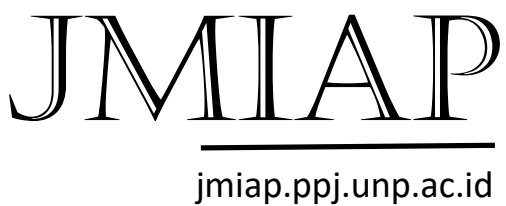

triangulasi digunakan untuk mencocokan sumber dari penulis peroleh seperti wawancara, observasi, dan studi kepustakaan.

\section{Hasil Penelitian dan Pembahasan \\ a. Pelaksanaan Pengembangan Pembangunan Infrastruktur di Kawasan Jalan Baru Muaro - Air Manis, Kelurahan Bukit Gado-Gado Kota Padang.}

Strategi pengembangan tata ruang terkait dengan tujuan dan konsep pengembangan tata ruang yang ditetapkan, sehingga setiap bagian wilayah semakin kuat dan berdaya atas dasar potensi yang dimiliki (Mahi, 2016). Strategi pengembangan tata ruang dilakukan melalui :

\section{Pengendalian secara konsisten.}

Untuk menjalankan strategi tersebut, proses kesepakatan mengenai delineasi kawasan lindung yang lebih realistis menjadi sangat penting dan perlu diikuti oleh implementasi pemanfaatan ruang dan pengendaliannya secara taat asas. Hal ini bertujuan untuk menjaga fungsi ekologis pada kawasan wisata terpadu. Oleh karena itu, terdapat syarat-syarat dalam mendirikan bangunan yaitu bangunan yang ramah lingkungan dan bangunan ringan sejenis lainnya.

Hasil wawancara peneliti dengan salah seorang Camat Padang Selatan, berikut pernyataanya :

"Untuk menjaga fungsi ekologis dan ekosistem di kawasan wisata terpadu maka bangunan yang berdiri merupakan bangunan ringan dan ramah lingkungan, hal tersebut di
JURNAL ILMU ADMINISTRASI PUBLIK

Email : jianfis.unp@gmail.com

Vol.1 No.1 Tahun 2018

karnakan pada kawasan tersebut rawan longsor, banjir rob, dan lainlain. Namun pada kenyataannya masih terdapat bangunan baton yang didirikan pada kawasan tersebut sehingga permasalahan ini menjadi perhatian khusus"

Dari wawancara di atas dapat disimpulkan bahwa pengembangan pembangunan infrastruktur boleh dilakukan di kawasan Bukit Gado-Gado namun pembangunan harus dilaksanakan sesuai dengan ketentuan yang berlaku demi menjaga keseimbangan ekosistem. Hasil penelitian penulis melalui wawancara menunjukkan bahwa pelaksanaan pengembangan pembangunan infrastruktur yang telah dilaksanakan dikawasan Bukit Gado-Gado tetap memperhatikan ekosistem dan kelestarian hutan dikawasan tersebut. Tujuan menjaga ekosistem dan kelestarian hutan tidak lain adalah untuk menjaga fungsi ekologis pada kawasan wisata terpadu oleh karenanya terdapat syaratsyarat dalam mendirikan bangunan seperti bangunan ramah lingkungan dan merupakan bangunan riang sejenis lainnya. Upaya ini dilakukan oleh pemerintah mengingat kawasan tersebut adalah kawasan rawan longsor dan banjir rob sehingga pendirian bangunan dikawasan tersebut perlu diberikan perhatian khusus.

2. Memperkuat basis perekonomian.

Dalam strategi ini identifikasi sumber daya alam yang mencakup skala dan nilainya menjadi penting untuk perkuatan dan perluasan aktivitas andalan bagi setiap bagian wilayah. Tujuan pelaksanaan pengembangan pembangunan infrastruktur yaitu untuk memaksimalkan potensi parawisata. 


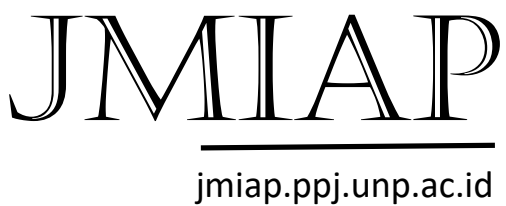

Hasil wawancara peneliti dengan salah seorang Sekretaris Lurah Bukit GadoGado, yang menyatakan bahwa :

"Dengan adanya pelaksanaan pengembangan pembangunan maka dapat meningkatkan potensi parawisata sebagai akibatnya tingkat perekonomian juga akan meningkat.”

Dari wawancara di atas dapat disimpulkan bahwa pengembangan infrastruktur yang baik dapat meningkatkan jumlah wisatawan yang berkunjung dikawasan parawisata, oleh karnanya pendapatan daerah pun menjadi meningkat sehingga tingkat perekonomian tumbuh menjadi lebih baik. Tujuan pelaksanaan pengembangan pembangunan infrastruktur yaitu untuk memaksimalkan potensi parawisata dikawasan Bukit Gado-Gado seperti Pantai Air Manis, dan panorama pesona Bukit Gado-Gado. Dengan dibangunannya infrastruktur yang baik maka dapat menarik masyarakat setempat atau dari luar daerah untuk dapat mengunjungi kawasan wisata tersebut. Semakin banyak masyarakat yang mengunjugi kawasan wisata Bukit GadoGado maka pendapatan daerah dari sektor parawisata akan bertambah yang memberikan dampak peningkaan perekonomian Kota Padang. Selain dari sektor parawisata dengan adanya infrastruktur yang baik maka dapat mempermudah jalur pendistribusian barang ataupun jasa.

3. Membentuk pengembangan efisien.
JURNAL ILMU ADMINISTRASI PUBLIK

Email : jianfis.unp@gmail.com

Vol.1 No.1 Tahun 2018

Satuan ruang pengembangan diharapkan menjadi lebih terbatas skalanya, namun jumlahnya menjadi lebih besar. Prinsip yang dianut adalah terciptanya skala ruang yang lebih terjangkau oleh suatu pusat dengan hinterland-nya, sehingga skala ekonomi suatu usaha dapat dicapai oleh sektor perekonomian. Dengan adanya pengembangan pembangunan infrastruktur maka dari segi aksesibilitas, kondisi fisik wilayah diharapkan yang pada awalnya terbatas namun kini dapat bermanfaat bagi masyarakat sekitar wilayah tersebut.

Berdasarkan wawancara dengan Kabid Bina Marga Dinas PUPR Kota Padang, yakni sebagai berikut :

"Dari segi efesiensi aksesabilatas pengembangan pembangunan infrastruktur seperti jalan baru yang dibangun sampai ke daerah teluk bayur dapat memudahkan akses menuju padang, serta menghindarkan kemacetan."

Dari wawancara di atas disimpulkan bahwa dengan adanya pengembangan pembangunan infrastruktur maka aktifitas sehari-hari akan lebih efesien dari aksesibilitasnya hal tersebut dikarenakan, kawasan Jalan Baru ini mampu dijadikan sebagai jalan alternatif untuk menghindari kemacetan akibat banyaknya jumlah wisatawan yang berkunjung pada kawasan tersebut. Dengan adanya pengembangan pembangunan infrastruktur maka dari segi aksesibilitas, kondisi fisik wilayah diharapkan yang pada awalnya terbatas namun kini dapat bermanfaat bagi masyarakat sekitar wilayah tersebut, 
dimana dengan adanya pembangunan ini dapat tercipta skala ruang yang lebih terjangkau seperti pembangunan jalan baru yang dibangun sampai ke daerah Teluk Bayur dimana tujuannya yaitu untuk memudahkan akses menuju Padang serta dapat dijadikan sebagai jalan alternatif untuk menghindari kemacetan terlebih pada hari-hari tertentu seperti hari libur dan akhir pekan. Dapat disimpulkan semakin pesatnya pembangunan infrastruktur pada kawasan tersebut maka aktifitas masyarakat sekitar jauh lebih efisien.

\section{b. Faktor-faktor penghambat pengembangan pembangunan infrastruktur kawasan Jalan Baru Muaro Air Manis, Kelurahan Bukit Gado-Gado Kota Padang.}

Pelaksanaan pengembangan pembangunan infrastruktur ditemukan beberapa faktor penghambat diantaranya dibedakan menjadi dua yaitu faktor internal dan eksternal seperti

1. Faktor Internal : Hambatan yang dihadapi oleh pemerintah Kota Padang terhadap pembangunan infrastruktur di kawasan Jalan Baru Muaro - Air Manis adalah keterbatasan kuantitas maupun kualitas dari personil aparatur negeri sipil (ASN). Hal ini sejalan dengan yang dilakukan pada pengalaman KPPIP untuk fasilitasi dan ipembangunan infrastruktur, dimana mereka menyatakan pembangunan infrastruktur melibatkan banyak pihak, mulai dari penanggung jawab proyek, kementerian/lembaga
JURNAL ILMU ADMINISTRASI PUBLIK

Email : jianfis.unp@gmail.com

Vol.1 No.1 Tahun 2018

terkait, pemerintah daerah, pemerintah desa, hingga masyarakat secara langsung, menyebabkan sulitnya mencari titik temu dalam merencanakan proyek secara matang (KPPIP, 2017).

Berdasarkan wawancara oleh Camat Padang Selatan :

"Faktor penghambat dari sisi internal adanya keterbatasan secara kuantitas maupun kualitas seperti keterbatasan personil Aparatur Negeri Sipil (ASN) dan minimnya kualitas beberapa anggota baik di kantor camat maupun kantor lurah. Juga pemahaman masyarakat terkait Perda bertolak belakang."

Dapat disimpulkan dari hasil wawancara diatas yaitu, bahwa hambatan yang dihadapi pemerintah Kota Padang tidak hanya bersumber dari masyarakat namun dapat ditemui juga hambatan yang berasal dari pemerintah terkait pembangunan infrastruktur dikawasan tersebut.

2. Faktor Eksternal : Rendahnya pemahaman masyarakat mengenai peraturan daerah khususnya mengenai RTRW serta mengenai pembebasan lahan untuk masyarakat itu sendiri. Hal ini mengakibatkan masyarakat bertindak tidak sesuai dengan peraturan yang ada. Hal ini sejalan dengan yang dilakukan Komite Percepatan Penyediaan Infrastruktur Prioritas (KPPIP, 2017) dimana dalam pengalamannya untuk fasilitasi dan pendampingan pembangunan infrastruktur yang 
dilakukan terutama yang masuk dalam PSN dan proyek prioritas, ditemukan 3 isu besar yang menjadi tantangan dalam percepatan pembangunan infrastruktur di Indonesia. Salah satunya adalah hambatan yang bersumber dari masyarakat mengenai isu pembebasan lahan terhadap lokasi pembangunan.

Berdasarkan wawancara peneliti oleh Kabid Pemetaan dan Penataan Ruang, berikut penuturannya :

"Rendahnya pemahaman masyarakat tentang peraturan daerah No.4 Tahun 2012 tentang RTRW Kota Padang yang melarang mendirikan bangunan liar tanpa izin mendirikan bangunan (IMB), hal ini diakibatkan karena tidak adanya program sosialisasi khusus tentang Perda tersebut. Sebagian besar masyarakat telah mengetahui adanya peraturan mengenai Izin Mendirikan Bangunan, namun masyarakat menghiraukan hal tersebut."

Dari hasil wawancara tersebut terlihat bahwa begitu rendahnya kesadaran masyarakat untuk mematuhi perarutran yang telah ditetapkan oleh pemerintah daerah, mereka hanya mendahulukan kepentingan diri mereka sendiri tanpa menyadari dampak negatif yang mereka timbulkan seperti buruknya tata ruang wilayah pada kawasan tersebut.

\section{c. Implikasi dari pengembangan pembangunan infrastruktur kawasan Jalan Baru Muaro Air Manis Terhadap Tata Ruang Di Kelurahan Bukit Gado-Gado Kota Padang.}

JURNAL ILMU ADMINISTRASI PUBLIK

Email : jianfis.unp@gmail.com Vol.1 No.1 Tahun 2018

Terdapat beberapa implikasi baik positif maupun negatif, diantaranya :

1. Implikasi Positif, Dengan dibangunnya infrastruktur seperti dibangunya jalan baru maka daerah tersebut akan memiliki nilai ekonomi yang tinggi karena adanya kemudahan akses jalan baik untuk aktifitas keseharian masyarakat setempat, mudahnya akses pendistribusian barang, dan mudahnya masyarakat dalam mengunjugi tempattempat wisata. Tingginya minat masyarakat pada daerah tersebut maka secara otomatis nilai tanah pada kawasan Bukit Gado-Gado juga akan mengalami peningkatan harga. Selain ketiga implikasi tersebut implikasi positif lainnya yaitu menurunnya tingkat pengangguran didaerah kawasan Bukit Gado-Gado. Penurunan tingkat pengangguran ini dikarenakan tingginya minat masyarakat setempat untuk berdagang di sepanjang Jalan Baru Muaro - Air Manis.

2. Implikasi Negatif, banyaknya bangunan yang permanen dan tidak permanen yang berdiri di sekitar kawasan tersebut tetapi tidak memiliki perizinan mendirikan bangunan (IMB). Selain itu banyaknya sampah yang berserakan ditepi jalan, hal ini dikarenakan banyaknya pengunjung yang membeli makanan dan minuman yang di sepanjang jalan.

Selain implikasi positif terdapat implikasi negatif yang terjadi akibat pengembangan pembangunan infrastruktur seperti halnya banyaknya bangunan yang permanen dan tidak permanen yang berdiri disekitar kawasan 
tersebut tetapi tidak memiliki perizinan mendirikan bangunan (IMB). Banyak nya masyarakat yang tidak memiliki perinzinan dikarenakan pada umumnya masyarakat tidak mendirikan bangunan diatas tanah mereka miliki sendiri. Kalaupun tanah tersebut milik mereka, tanah tersebut belum memiliki sertifikasi sehingga belum adanya keabsahan status tanah tersebut. Selain bangunan tempat tinggal masyarakat banyak juga ditemukan kedai-kedai yang tidak memiliki izin mendirikan bangunan. Banyaknya bangunan liar yang berjualan ditepi jalan maka menutupi keindahan pemandangan disepanjang jalan yang menghadap ke pantai.

Dampak negatif lainnya yaitu banyaknya sampah yang berserakan ditepi jalan, hal ini dikarenakan banyaknya pengunjung yang membeli makanan dan minuman yang disepanjang jalan namun belum adanya tempat penampungan sampah ataupun mobil pengangkut sampah baik bagi penjual maupun pengunjung jalan. Sehingga masyarakat setempat maupun penjual harus menempuh jarak yang cukup jauh untuk membuang sampah mereka. Implikasi yang terakhir yaitu karena belom adanya penerangan jalan maka masyarakat setempat biasanya tidak akan melintasi jalan tersebut diatas pukul 19.00 malam. Tanpa ada penerangan jalan maka dapat memicu banyaknya anak-anak muda yang berbuat maksiat.

\section{Penutup}

Kesimpulan
JURNAL ILMU ADMINISTRASI PUBLIK

Email : jianfis.unp@gmail.com

Vol.1 No.1 Tahun 2018

Berdasarkan hasil penelitian dan pembahasan yang telah diuraikan di atas, dapat disimpulkan bahwa:

1. Implikasi positif, dengan dibangunnya infrastruktur pada kawasan tersebut maka akses jalan untuk aktifitas keseharian masyarakat maupun pendistribusian barang dapat terpenuhi dengan baik, menurunnya tingkat pengangguran, meningkatnya potensi parawisata pada kawasan pantai air manis dan adanya perbaikan ekonomi masyarakat pada kawasan tersebut.

2. Implikasi negatif, banyaknya bangunan yang tidak memiliki izin mendirikan

bangunan (IMB), berkurangnya
keindahan panorama akibat
banyaknya bangunan liar dan
banyaknya sampah yang berserakan
ditepi jalan serta kurangnya
penerangan dapat memicu perbuatan
prilaku menyimpang.

\section{Saran}

Berdasarkan hasil penelitian dan kesimpulan yang telah diuraikan di atas, maka penulis mengemukakan saran-saran sebagai berikut:

1. Saran kepada masyarakat di kawasan Bukit Gado-Gado yaitu agar dapat mematuhi aturan yang telah ditentukan pemerintah Kota Padang khususnya seperti untuk tidak mendirikan bangunan liar dan mendirikan bangunan yang memiliki perizinan dari pemerintah. Hal 
JMIAP

tersebut dikarenakan tujuan dibentuknya Peraturan Daerah no. 4 tahun 2012 tidak lain adalah untuk kepentingan bersama masyarakat Kota Padang pada umumnya dan masyarakat dikawasan Bukit GadoGado pada khususnya. Selain itu masyarakat juga dapat menjaga kebersihan lingkungan untuk tetap terjaganya keindahan panorama didaerah tersebut.

2. Saran kepada Pemerintah terkait yaitu dalam pelaksanaan pengembangan infrastruktur agar dapat memberikan sosialisasi kepada masyarakat agar pentingnya menjaga keindahan tata ruang wilayah kota, pemerintahan juga perlu melakukan pengawasan secara berkala agar tidak bertambahnya jumlah bangunan liar yang didirikan oleh masyarakat sekitar, serta pemerintah juga perlu memberi fasilitas yang menunjang pembangunan infrastruktur seperti halnya menyediakan penerangan jalan, rambu-rambu lalu lintas, pembatas jalan, bangunan khusus untuk pedagang, dan tempat pembuangan sampah yang memadai.

\section{DAFTAR KEPUSTAKAAN}

Hayani. (2012). Bunga Rampai Tata Ruang Kota Padang. Padang : Bung Hatta University Press.

Kodoatie, Robert J. (2010). Tata Ruang Air. Yogyakarta : C.V ANDI OFFSET.

Mahi, Ali Kabul. (2016). Pengembangan wilayah. Jakarta : KENCANA.
JURNAL ILMU ADMINISTRASI PUBLIK

Email : jianfis.unp@gmail.com

Vol.1 No.1 Tahun 2018

Mankiw, N. Gregory. (2003). Teori makro ekonomi edisi kelima. Terjemahan. Jakarta : Erlangga.

Pemendagri No.1, (2007) Tentang Penataan Ruang Terbuka Hijau Di Wilayah Perkotaan.

Peraturan Daerah Kota Padang Nomor 4 Tahun 2012 Tentang Rencana Tata Ruang Wilayah Kota Padang.

Suwantoro, Gamal. (1997). Dasar-dasar parawisata. Jogjakarta : Andi Offset.

Undang-Undang Nomor 26 Tahun 2007 Tentang Penataan Ruang.

Utomo, Wahyu. (2017). Tantangan pembangunan infrastruktur di Indonesia.

Sumber:https://kppip.go.id/opini /tantangan-pembangunaninfrastruktur-indonesia/

Direktorat Pengembangan Kawasan Strategis, Ditjen Penataan Ruang, Departemen Permukiman dan Prasarana Wilayah, 2002

KBBI, 2017. Kamus Besar Bahasa Indonesia (KBBI). Sumber: http://kbbi.web.id/pusat, 